\title{
Front Matter: Volume 9075
}

, "Front Matter: Volume 9075," Proc. SPIE 9075, Biometric and Surveillance Technology for Human and Activity Identification XI, 907501 (6 June 2014); doi: $10.1117 / 12.2072098$

SPIE. Event: SPIE Defense + Security, 2014, Baltimore, MD, United States 


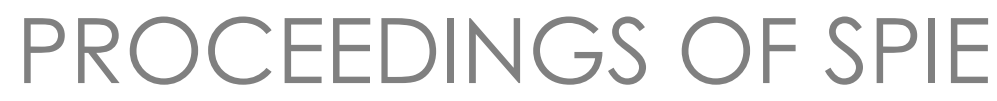

\section{Biometric and Surveillance Technology for Human and Activity Identification XI}

loannis A. Kakadiaris

Walter J. Scheirer

Christoph Busch

Editors

8 May 2014

Baltimore, Maryland, United States

Sponsored and Published by

SPIE 
The papers included in this volume were part of the technical conference cited on the cover and title page. Papers were selected and subject to review by the editors and conference program committee. Some conference presentations may not be available for publication. The papers published in these proceedings reflect the work and thoughts of the authors and are published herein as submitted. The publisher is not responsible for the validity of the information or for any outcomes resulting from reliance thereon.

Please use the following format to cite material from this book:

Author(s), "Title of Paper," in Biometric and Surveillance Technology for Human and Activity Identification XI, edited by loannis A. Kakadiaris, Walter J. Scheirer, Christoph Busch, Proceedings of SPIE Vol. 9075 (SPIE, Bellingham, WA, 2014) Article CID Number.

ISSN: 0277-786X

ISBN: 9781628410129

Published by

SPIE

P.O. Box 10, Bellingham, Washington 98227-0010 USA

Telephone +1 3606763290 (Pacific Time) · Fax +1 3606471445

SPIE.org

Copyright (@ 2014, Society of Photo-Optical Instrumentation Engineers.

Copying of material in this book for internal or personal use, or for the internal or personal use of specific clients, beyond the fair use provisions granted by the U.S. Copyright Law is authorized by SPIE subject to payment of copying fees. The Transactional Reporting Service base fee for this volume is $\$ 18.00$ per article (or portion thereof), which should be paid directly to the Copyright Clearance Center (CCC), 222 Rosewood Drive, Danvers, MA 01923. Payment may also be made electronically through CCC Online at copyright.com. Other copying for republication, resale, advertising or promotion, or any form of systematic or multiple reproduction of any material in this book is prohibited except with permission in writing from the publisher. The CCC fee code is 0277-786X/14/\$18.00.

Printed in the United States of America.

Publication of record for individual papers is online in the SPIE Digital Library.

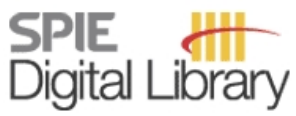

SPIEDigitalLibrary.org

Paper Numbering: Proceedings of SPIE follow an e-First publication model, with papers published first online and then in print and on CD-ROM. Papers are published as they are submitted and meet publication criteria. A unique, consistent, permanent citation identifier (CID) number is assigned to each article at the time of the first publication. Utilization of CIDs allows articles to be fully citable as soon as they are published online, and connects the same identifier to all online, print, and electronic versions of the publication. SPIE uses a six-digit CID article numbering system in which:

- The first four digits correspond to the SPIE volume number.

- The last two digits indicate publication order within the volume using a Base 36 numbering

system employing both numerals and letters. These two-number sets start with 00, 01, 02, 03, 04, $05,06,07,08,09,0 A, 0 B \ldots$. 0Z, followed by 10-1Z, 20-2Z, etc.

The CID Number appears on each page of the manuscript. The complete citation is used on the first page, and an abbreviated version on subsequent pages. Numbers in the index correspond to the last two digits of the six-digit CID Number. 


\section{Contents}

$\checkmark$ Conference Committee

FINGERPRINT BIOMETRICS

907503 Finger image quality based on singular point localization [9075-2]

J. Wang, Technical Univ. of Denmark (Denmark) and Ctr. for Advanced Security Research

Darmstadt (Germany); M. A. Olsen, Ctr. for Advanced Security Research Darmstadt

(Germany) and Norwegian Information Security Lab. (Norway); C. Busch, Norwegian

Information Security Lab. (Norway)

907504 On the fly finger knuckle print authentication [9075-3]

N. Abe, T. Shinzaki, Fujitsu Labs., Ltd. (Japan)

907505 Interpretation of fingerprint image quality features extracted by self-organizing maps [9075-4]

I. Danov, Technical Univ. of Denmark (Denmark) and Ctr. for Advanced Security Research

Darmstadt (Germany); M. A. Olsen, Ctr. for Advanced Security Research Darmstadt

(Germany); C. Busch, Norwegian Information Security Lab. (Norway)

\section{FACE AND IRIS BIOMETRICS}

907506 Multimodal biometrics system based on face profile and ear [9075-5]

I. S. Youssef, Cairo Univ. (Egypt); A. A. Abaza, Cairo Univ. (Egypt) and West Virginia High Tech Foundation (United States); M. E. Rasmy, A. M. Badawi, Cairo Univ. (Egypt)

907507 3D face recognition based on the hierarchical score-level fusion classifiers [9075-6] Š. Mráček, J. Váňa, K. Lankašová, M. Drahanský, M. Doležel, Brno Univ. of Technology (Czech Republic)

907508 A statistical investigation into the stability of iris recognition in diverse population sets [9075-7]

J. J. Howard, D. M. Etter, Southern Methodist Univ. (United States)

NOVEL MODALITIES

$90750 \mathrm{~A}$ Template aging in eye movement-driven biometrics [9075-9]

O. V. Komogortsev, C. D. Holland, A. Karpov, Texas State Univ. San Marcos (United States)

9075 OB Human thermal modeling to augment MWIR image analysis in surveillance applications [9075-10]

R. L. Woodyard, J. A. Skipper, Wright State Univ. (United States) 
9075 OD Secure fingerprint hashes using subsets of local structures [9075-12]

T. Effland, M. Schneggenburger, J. Schuler, Univ. at Buffalo (United States); B. Zhang, Univ. at Buffalo (United States) and National and Kapodistrian Univ. of Athens (Greece);

J. Hartloff, J. Dobler, S. Tulyakov, A. Rudra, V. Govindaraju, Univ. at Buffalo (United States)

9075 OE En-face full-field optical coherence tomography for fast and efficient fingerprints acquisition [9075-13]

F. Harms, E. Dalimier, LLTech Pépinière (France); A. C. Boccara, LLTech Pépinière (France)

and Institut Langevin ESPCI-ParisTech (France)

\section{POSTER SESSION}

$90750 F \quad$ Exploiting quality and texture features to estimate age and gender from fingerprints [9075-14]

E. Marasco, L. Lugini, B. Cukic, West Virginia Univ. (United States)

$9075 \mathrm{OH} \quad$ Detection of latent fingerprints by near-infrared spectral imaging [9075-16]

W. Huang, Institute of Forensic Science (China); Y. Dai, Police College of Sichuan (China)

9075 0J Facial biometrics based on 2D vector geometry [9075-18]

O. Malek, A. Venetsanopoulos, D. Androutsos, Ryerson Univ. (Canada)

9075 OK Remote authentication using vaulted fingerprint verification [9075-21]

H. Alzahrani, T. E. Boult, Univ. of Colorado at Colorado Springs (United States)

$9075 \mathrm{OL} \quad$ Mobile user identity sensing using the motion sensor [9075-22]

X. Zhao, T. Feng, L. Xu, W. Shi, Univ. of Houston (United States)

9075 OM Biometric recognition via fixation density maps [9075-23]

I. Rigas, O. V. Komogortsev, Texas State Univ. San Marcos (United States)

Author Index

iv 


\title{
Conference Committee
}

\author{
Symposium Chair
}

David A. Whelan, Boeing Defense, Space, and Security (United States)

Symposium Co-chair

Nils R. Sandell Jr., Strategic Technology Office, DARPA (United States)

Conference Chairs

loannis A. Kakadiaris, University of Houston (United States)

Walter J. Scheirer, Harvard University (United States)

Christoph Busch, Fraunhofer-Institut für Graphische

Datenverarbeitung (Germany) and Norwegian Information Security Laboratory (Norway)

Conference Program Committee

J. Ross Beveridge, Colorado State University (United States)

Terrance E. Boult, University of Colorado at Colorado Springs (United States)

Rama Chellappa, University of Maryland, College Park (United States)

Bernadette Dorizzi, TELECOM \& Management SudParis (France)

Julian Fierrez, Universidad Autónoma de Madrid (Spain)

Patrick J. Flynn, University of Notre Dame (United States)

Brian C. Heflin, University of Colorado at Colorado Springs (United States)

Ajay Kumar, The Hong Kong Polytechnic University (Hong Kong, China)

Daniel P. Lopresti, Lehigh University (United States)

Norman Poh, University of Surrey (United Kingdom)

Nalini K. Ratha, IBM Thomas J. Watson Research Center (United States)

Anderson Rocha, Universidade Estadual de Campinas (Brazil)

Arun A. Ross, Michigan State University (United States)

Natalia A. Schmid, West Virginia University (United States)

Stephanie Schuckers, Clarkson University (United States)

William R. Schwartz, Universidade Federal de Minas Gerais (Brazil)

Shishir Shah, University of Houston (United States)

Kar-Ann Toh, Yonsei University (Korea, Republic of)

Raymond N. J. Veldhuis, Universiteit Twente (Netherlands)

Ruigang Yang, University of Kentucky (United States) 
Proc. of SPIE Vol. $9075907501-6$

Downloaded From: https://www.spiedigitallibrary.org/conference-proceedings-of-spie on 26 Apr 2023 Terms of Use: https://www.spiedigitallibrary.org/terms-of-use 